\title{
Testing Green Financing for Greater Renewable Electricity Generation and Energy Efficiency: Implications for Post COVID-19 Time
}

Zhen Liu ( $\sim$ zhenliu_cn@yahoo.com )

Nanjing Normal University https://orcid.org/0000-0002-9770-1692

Jinhang Xu

Nanjing Normal University

Yiming Wei

Nanjing Normal University

Assem Abu Hatab

Swedish University of Agricultural Sciences

Jing Lan

Nanjing Agricultural University

\section{Research Article}

Keywords: green financing, energy efficiency, environmental initiatives, post COVID-19 period, climate change

Posted Date: August 10th, 2021

DOl: https://doi.org/10.21203/rs.3.rs-755722/v1

License: (c) (i) This work is licensed under a Creative Commons Attribution 4.0 International License. Read Full License 


\section{Abstract}

There is a possibility that worldwide expenditures in renewable energy and energy efficiency projects could fall much further in 2017 and 2018. This may jeopardize the Sustainable Development Goals (SDGs) and the Paris climate change agreement. Lack of access to private financing slows the development of green initiatives. Now that sustainable energy isn't about science and technology, it's all about getting financing. Therefore, recent study intended to investigate the role of green financing for maximum renewable electricity generation and efficiency of energy in United States of America (USA). Our study suggested to value environmental initiatives, like other infrastructure initiatives, for greater electricity generation and energy efficiency in USA. Such infrastructural projects need long-term financing and capital-intensiveness. Our findings suggest that to sustain growth, development, and energy poverty reduction, around \$26 trillion would be required, in terms of green financing, in the USA alone by the year 2030 to enhance energy efficiency. To achieve energy sustainability goals in USA, recent research suggested some policy implication considering the post COVID-19 time. If suggested policy implications are implemented successfully there are chances that green financing would make energy generation and energy efficiency as effective.

\section{Introduction}

There is a possibility that worldwide expenditures in renewable energy and energy efficiency projects could fall much further in 2017 and 2018 (Gielen et al, 2019). This may jeopardize the Sustainable Development Goals (SDGs) and the Paris climate change agreement (Alemzero et al, 2021). Lack of access to private financing slows the development of green initiatives. Now that sustainable energy isn't about science and technology, it's all about getting financing (lqbal et al, 2021). A lot of people regard environmental initiatives, like other infrastructure initiatives. Infrastructural projects are long-term and capital-intensive. The Asian Development Bank claims that to sustain growth, development, and poverty reduction, $\$ 26$ trillion would be required in the area alone by the year 2030 . The majority of the $\$ 14.7$ trillion overall investment requirements for the period 2016-2030 will be for energy (power).

When it comes to green energy initiatives, two key problems exist: (a) lesser returns, and (b) a larger risk of investment. Banks don't fund green energy projects because of the inherent risk and because of the Basel capital requirements (Anh Tu et al, 2021). Risk is difficult to protect since traditionally, utility prices were distributed among customers in regulated utility service. But because of the absence of PPA contracts in developing nations, uncertainty is increased and investment is made more risky. The third main factor for the shrinking new investment in renewable energy is fast technology advancement and cost reduction. Renewable energy technologies cost less thanks to technology advancements. Averaged over the 2009-2016 period, PV module costs have decreased by $80 \%$, while wind turbine costs have decreased by between $30-40 \%$. However, this news leads investors to halt and observe how far the prices would fall on the opposite side (Iqbal et al, 2021). 
Problems for renewable energy continued with the COVID-19 outbreak (Iqbal et al, 2021). Incubation of corona positive individuals (a health emergency) combined with a fall in the energy market because of unanticipated decrease in oil prices (lqbal et al, 2020). As a result, these challenges plunged world economies into a recession (Yoshino et al, 2021). Besides, efficiency is influenced by climate change and improved responses of carbon emission during the epidemic (Alemzero et al, 2021). The estimations revealed that during pandemic lockdown, $17 \%$ of the world's climatic changes were recorded, and this shift decreased energy efficiency by $32 \%$. Carbon output is projected to decrease in the pandemic era and there is a likelihood of a $1.2 \%$ drop in energy efficiency. Another research by lqbal et al (2020) found that the COVID-19 crisis had caused a 10\% decline in energy efficiency. This suggests that more populous and oil-addicted nations witnessed a major decrease in energy efficiency (Anh Tu et al, 2021).

Renewable power production and energy efficiency funding have been seen as significant concerns in rising seven economies (e.g. E7) as resource-intensive and carbon-based growth increases (Child et al, 2018). Carbon-intensive economies are also popular growing economies. The two estimates show a large growth in the PE in the US, Japan, and the rest of the world's global Renewable electricity generation (Campisi et al, 2018). Emerging nation's population rose by 36\%, from 2.9 billion to 4.0 billion, throughout the decade 2000-2015. That Asia is poised to have a major impact on the world's food security as it grows in significance with respect to population and economic power in the latter option (Kabir et al, 2018). Many nations, particularly those in the early phases of development, are vulnerable to losing both their environmental variety and health from climate change.

Increased environmental change now boosts the need for solid and long-term energy solutions (Mohsin et al, 2021). Greening the economy is the most powerful path to take. Sustaining the energy system and increasing energy efficiency need some proactive public assistance (Taghizadeh-Hesary and Rasoulinezhad, 2020). Also, this fosters economic resource mobility and economic development under eco-environment openness ( $\mathrm{Li}$ et al, 2021). So governmental incentives to promote energy efficiency help spur green development by reducing carbon emissions (Cheng et al, 2020). Reducing our reliance on fossil fuels is important in today's time, amid the COVID-19 epidemic (Iqbal et al, 2021). The latest research contributes to a better understanding of critical factors that influence public supports for renewable energy (Corrocher and Cappa, 2020). Too far, no comprehensive research on renewable energy and public support has been done. While public papers from various government agencies and ministries offer the foundation for future research in linking these constructions. can give theoretical assist in creating the theoretical framework connecting public subsidies and energy efficiency in crisis periods During the period from 2014-2017, \$2 trillion will be spent in these three sectors following the COVID-19 outbreak. Public sources said that $\$ X$ in green energy financing will be spent in renewable, clean, and green energy projects (Taghizadeh-Hesary and Yoshino, 2020).

Extending to it, green financing has become a vital way forward to finance for the environment related issues to clean (Falcon and Sica, 2019). Such financing technique is modern tool giving way to the global world for financing and managing environment and growth related aspects helping economies to sustain Loading [MathJax]/jax/output/CommonHTML/jax.js ncing through green financing is modern solution to the 
globe for green development (Zhou, Tang and Zhang, 2020). One of the obstacles for green development is how to effectively finance green projects from the public, private and not-for-profit sectors (UN Environment). This argument unlocked the new avenues of financing and holds the potential to replace traditional modes of financing, such as, government subsidies and public financing (Bal et al, 2014). Importantly, there is a dire need to develop the market mechanism that can pool financial markets more effectively to fund green projects (Wang and Zhi, 2016).

Green financing is the latest financing option. Previous studies highlighted that green financing are less studied in the domain of renewable electricity generation energy efficiency systems and warranted to investigate to add up in the body of knowledge by giving solutions to for post COVID-19 time. To the best of our reading, none of study is found studying green bonds, energy efficiency investment and economic growth, and presenting way forwards to manage the post COVID-19 time. However, there is a need to test green financing with renewable electricity generation for energy efficiency and to present the policy implications controlling the post COVID-19 tenure. Hence, the objective of the study is to test this novel connection between these constructs and present best possible solutions to the associated stakeholders.

\section{Literature Review}

Many countries the cleanest environment of any nation in the world, excelling in air quality, sanitation, clean drinking water, waste management, and addressing climate change with a goal to reduce GHG emissions by $70 \%$ by 2030 (Mihelcic and Zimmerman, 2021). A long history of success in renewable energy development is evident (Kilkis, 2019). Developing renewable energy to stabilise the environment is something to learn from this all. This is evidence that the government can close the gap between investment payments and renewable sector revenues by implementing suitable legislation (Shahbaz et al, 2020). Most electricity in Denmark is generated by wind power. This nation has long relied on foreign oil. Energy dependence did not begin until the post-1973 oil crisis. Ever since then, Denmark has poured millions into renewables, notably wind power (Cheng and Yao, 2021). Renewable output accounted for $47 \%$ of total energy output in 2019. Denmark's aims are to provide more than half of their energy needs with renewables by 2030, and to have gotten rid of fossil fuels for energy production by 2050 .

A whole supply chain from commodities to components has been impacted by the COVID-19 epidemic. This is clear, since the power production in Denmark initially dropped since 2000. Other studies demonstrate that the reduction in gross power output may be linked to the reduction in net power output from wind turbines (Erdogan et al, 2020). Bloomberg New Energy Finance has suggested that over dependence on a single kind of renewable energy might be detrimental during emergency situations. The following discussion accounts for our findings (Bersalli, Menanteau and El-Methani, 2020). The outcomes of the COVID-19 pandemic are likely to vary greatly over the world, as a result of regional, national, and geopolitical factors. Therefore, unique characteristics, such tight containment procedures, first-aid, or palliative care, give information on the consequences of the pandemic. Delay of infection seemed to be less in Denmark compared to other European nations because to the installation of 
stringent lockdown, social distance, and government assistance (Caruso, Colantonio and Gattone, 2020). The short- and long-term consequences of these policies are without debate.

This mission complements the ultimate objective of sourcing all of her energy from carbon-free, environmentally-friendly sources (Kreps, 2020). The rise in renewable power production over the last decades and a significant potential (Göhlich et al, 2021). Since renewable energy sources have major economic implications, we must investigate how it is generated to comprehend the economic state postpandemic. Recently, a literary strand has explored environmental innovations' involvement with financial issues (Panwar, Kaushik and Kothari, 2011; Koronoes et al, 2003). Environmental innovation literature is sparse according to Johnson and Lybecker (2012). Ghisetti et al. (2015) conducted a study on environmental innovations among small and medium-sized companies inside the European Union, finding that financial constraints impede business' environmental innovations. to boost environmental innovation adoption, facilitate access to financing Iqbal et al, (2021) investigated the influence of funding limitations on innovation activities across 1300 European enterprises during the 1995-2009 period by using patents as a proxy for innovation and three other financial variables as funding sources. In order to advance innovative projects, it is essential to remove finance constraints. Despite lqbal et al, (2021)'s explanatory study which attempts to prove a connection between funding and green innovation, the scant research on finance restrictions on green innovation persists.

Further, funding limits will vary depending on the form of ownership. The available research demonstrates that SOEs have primarily been able to spend in R\&D for innovation because of loan guarantees and access to state-owned banks (Anh Tu et al, 2021). However, another branch of research argues that state ownership and political features are not the driving forces in the private equity market, and so raise financing limits (Mohsin et al, 2019). Additionally, Li et al, (2021) observed that state ownership effects investment in R\&D by loosening finance limitations and constraining the innovativeness of state-owned companies.

Since investing in energy efficiency would boost contract win rates, it also boosts the usage rates of the ships, and that may be a significant consideration in an oversupplied market (Tiwari and Mishra, 2012; Maczulak, 2010). Despite that, energy efficiency is unlikely to be completely reflected in charter prices owing to the ambiguity as to whether the market would compensate for fuel efficient ships (Agnolucci et al., 2014). Ship-owners must either own their own ships or enter into long-term arrangements with charterers if they want to recuperate their investments in fuel economy. Furthermore, Tiwari and Mishra, (2012) observe that charterers may be hesitant to pay a premium to represent energy efficiency, since it might decrease the number of potential charter customers by driving up shipping costs. Verifying fuel usage claims given by the owners also adds to that resistance. Ship management organizations' wariness about charter fees for both energy efficiency and investment in energy efficiency was also mentioned by Carrasco et al, (2006). Thus, the debate regarding the effects of energy efficiency relies on new technology, notably the financial risk associated with unproven fuel savings. Adding more costly, environment-friendly fuel is connected with slower speed and longer cargo time. However, better fuel Alemzero et al, 2021).

Page 5/22 
In addition, there is very little evidence that financial savings accrued from shipping fuel-efficient ships incentivizes ship-owners to purchase more fuel-efficient ships. In the instance of dry bulk shipping, Agnolucci et al. (2014) found that only $40 \%$ of the financial savings achieved by energy efficiency is received by ship-owners. Other dry bulk ship sizes were also covered in Adland et al. (2017). Less than half of the fuel cost reductions are shared with ship-owners by means of increased time charter charges, and only under normal market circumstances. Additionally, inefficient tonnage is often rewarded in rising markets. This has important implications for how time charter contracts set prices for energy efficiency. During prosperous times, owners of energy efficient tonnage might be punished. The findings of Winkel et al. (2015) are in favor of the adoption of smart charter contracts, in which speed choice is adjustable, the chartering fee is closer to the cost of fuel, and risks and profits are shared among charterers and shipowners.

It is interesting to note that renewable energy sources have considerable potential to preserve current energy consumption patterns and energy efficiency, but to do so, there is a large deal of public support required. International Energy Agency (IEA) calculated a total public support need of roughly \$16 trillion USD, stretching from 2015 to 2050. This idea is in-line with the Paris Agreement objective commitment. However, in the energy sector, support for energy efficiency is sluggish going (Barbier, 2020).

\section{Methodology}

\subsection{Data}

From two separate yearly polls conducted by the United States, data was obtained to help carry out our empirical study (EIA). In other words, surveys Form EIA-923 and Form EIA-861 should be done. Powerplant operating parameters were measured using the EIA-923 form on an annual basis, starting in 2013 and ending in 2017. In order to give information on the frequency and length of electricity system interruptions experienced by end-consumers, the EIA compiled data for the study of Form EIA861, which they had been collecting since 2013. Some utilities submitted data ranging from a few years to many decades. As a consequence, our dataset has 198 yearly observations between 2016 and 2020, with just half of the data included in each of those years.

\subsection{Measurement of the Constructs}

SAIDI is a score used to determine the length (typically measured in minutes) of interruptions in the power supply for end-users. the average time interruption lasts, which is often referred to as the system average interruption frequency index (SAIFI) (i.e., the number of times a customer has gone without power during the year). The IEEE designed two AI characters: SAIDI and SAIFI (1998). In standard terminology, the two indices are used by utilities that want to track the overall quality of their electrical grid (Eto et al., 2012).

In a DMU division, Tone uses slack-based effectiveness determination to find a unique opportunity (i.e., opportunity indicated by $\mathrm{DMUj},(\mathrm{j}=1, \ldots, \mathrm{n}))$. For this, an output unit serving the $\mathrm{DMU}$ for the empirical 
$R \mathrm{sk}^{\wedge}+$, and $\mathrm{z}$, which is set to $\mathrm{R} \mathrm{dk}^{\wedge}+$. More so, the invention opportunity indicating two-stage subsets with the following arrangement;

$$
\text { PPSstage } 1=\left\{(\mathrm{x}, \mathrm{z}) \mid \mathrm{x} \geqslant \sum_{j=1}^{n} \chi_{j} \lambda_{j}, z \leqslant \sum_{j=1}^{n} z_{j} \lambda_{j}, j=1, \ldots, n\right\}
$$

$$
\text { PPSstage } 1=\left\{(\mathrm{y}, \mathrm{z}) \mid \mathrm{z} \geqslant \sum_{j=1}^{n} z_{j} \mu_{j}, y \leqslant \sum_{j=1}^{n} y_{j} \mu_{j}, j=1, \ldots, n\right\}
$$

2

DMUk application adoption is a potential invention opportunity, which reveals its capability when extended with a dual-step identification that demonstrates DMUk's declaration of consistent evolved to the point where it could survive a construct with ejected well-organized units, and which show that the system could survive amorphous conditions. However, the study done on competent position DMUs employs an association structure. Therefore, the intermediate trial's weakness may impact the overall effect. The contribution of midway meals must be taken into consideration while assessing the efficiency and positioning of the competent unit. However, the study shows the a novel connected and integrated model using the ranking method on the basis oc outputs generate by the fundamental occurrence.

$$
r_{k}=\min \left(\frac{1}{m} \sum_{j=1}^{n} \frac{S_{i}^{-}}{X_{i k}}+\frac{1}{D} \sum_{d=1}^{D} \frac{T_{d}^{*}}{Z_{d k}}\right) /\left(1+\frac{1}{D} \sum_{d=1}^{D} \frac{R_{d}^{*}}{Z_{d k}}+\frac{1}{S} \sum_{r=1}^{S} \frac{S_{r}^{+}}{y_{r k}}\right)
$$

3

s.t. $\sum_{j=1}^{n} \lambda_{j} x_{i j}+s_{i}^{-}=X_{i k^{p}} i=1, \ldots, m$,

$\sum_{\substack{j=1 \\ j \neq k}}^{n} \mu_{j} y_{r j}-s_{r}^{+}=y_{r k}, r=1, \ldots, s$,

$\sum_{\substack{j=1 \\ j \neq k}}^{n} \lambda_{j} z_{d j}=z_{d k}+R_{d}^{*}, d=1, \ldots, D$,

$\sum_{\substack{j=1 \\ j \neq k}}^{n} \lambda_{j} z_{d j}=z_{d k}-T_{d}^{*}, d=1, \ldots, D$

$s_{r}^{+} \geqslant y_{r k}, r=1, \ldots, s$,

$s_{i}^{-} \geqslant 0, i=1, \ldots, m$,

$s_{r}^{+} \geqslant 0, r=1, \ldots, s$,

$\lambda_{j} \geqslant 0, \mu_{j} \geqslant 0 \otimes j=1, \ldots, n$.

In Eq. (10) an objective model is formed on the basis of supposed DMUs with $n$, whereas $m$ is indicated Loading [MathJax]/jax/output/CommonHTML/jax.js vering the scope of different non-energy sources and other 
power sources aligned with the range of yield customs, such as, $g_{j}=\left(g_{1 j}, \ldots, g_{s j}\right)$ and $b_{j}=\left(b_{1 j}, \ldots, b_{f j}\right)$, indicated with $f$ an undesired function for an output. Endorsing Eq. (9) the in recent tests, the RAM-DEA model has been used to quantify the power efficiency in unusual discard scenarios for each DMU. Attributes that are un-identical to each other but nonetheless connected are determined by the model's limitations.

$$
\max _{s, \lambda} \sum_{i=1}^{m} R_{i}^{X} S_{i}^{X}+\sum_{r=1}^{s} R_{r}^{g} S_{r}^{g}+\sum_{f=1}^{h} R_{f}^{b} s_{f}^{b}
$$

4

s.t. $\sum_{j=1}^{n} x_{i j} \lambda_{j}+s_{i}^{X}=x_{i j 0}, i=1, \ldots, m$,

$\sum_{j=1}^{n} g_{r j} \lambda_{j}-s_{i}^{g}=g_{r j 0}, r=1, \ldots, s$,

$\sum_{j=1}^{n} b_{f j} \lambda_{j}+s_{f}^{b}=b_{f j 0}, f=1, \ldots, h$,

$\sum_{j=1}^{n} \lambda_{j}=1$

$\lambda_{j} \geqslant 0, j=1, \ldots, n s_{i}^{X} \geqslant 0 \otimes i=1, \ldots, m$

$s_{r}^{g} \geqslant 0, r=1, \ldots, s s_{f}^{b} \geqslant 0 \otimes f=1, \ldots, h$

For empirical analysis, DEA based technique is used to assess the interplay between constructs in empirical way. However, study applied DEA technique to present the inference between the constructs.

\section{Results And Discussion}

\subsection{Empirical results}

This study examined 28 areas on the mainland of these countries, excluding the table on the basis of the lack of associated energy and release data and exclusion combined in Austria in Finland and together are considered a single region as a result of increasingly high energy efficiency and market reforms in Austria due to lack of separate data in Luxembourg. The model results of these countries therefore are many studies deal with energy efficiency and market changes, but do not reach the highest possible degree of energy efficiency. This research thoroughly proposes the creation of lower-cost power supplied across border nations for renewable energy marketplaces. This present research focuses on 28 high carbonstrong market reforms for new targets and low emissions with high primary energy dependence. We must Loading [MathJax]/jax/output/CommonHTML/jax.js :es, autonomous regions and municipalities further in terms 
of development and political considerations usually in three major categories: East, central and comprehensive data on areas and regions is shown in Table 1 and Table 2.

As indicated in Table 2 the eastern area includes 11 regions including eight coastal provinces, the fastest economic development in the past 30 years in those nations and the average GDP output throughout the research period (2010-2014) accounts for almost half of the total GDP in these countries. Most lighting and many heavy industries are situated in the eastern area, and the majority of foreign industrial and commercial services in those nations are located. This region also draws the biggest international investment and technology thanks to its comfortable transit system and infrastructure. These nations have high access to GDP and highest power use in all sectors. Today, greenhouse gases with green energy sources such as wind, solar, thermal and biogas are decreasing throughout the globe. Market changes are extremely beneficial to academics, researchers and governments. 
Table 1

Energy efficiency score - DEA methodology outputs from 2016 to 2020

\begin{tabular}{|llllll|}
\hline Countries & 2016 & 2017 & 2018 & 2019 & 2020 \\
\hline Austria & 0.344 & 0.656 & 0.467 & 0.557 & 0.707 \\
\hline Azerbaijani & 0.178 & 0.532 & 0.883 & 0.589 & 0.319 \\
\hline Belgium & 0.444 & 0.471 & 0.455 & 0.781 & 0.444 \\
\hline Chile & 0.732 & 0.314 & 0.555 & 0.789 & 0.567 \\
\hline Finland & 0.616 & 0.319 & 0.446 & 0.885 & 0.481 \\
\hline Germany & 0.222 & 1.267 & 1.498 & 1.808 & 0.513 \\
\hline Denmark & 0.567 & 0.370 & 0.441 & 0.456 & 0.289 \\
\hline Fiji & 0.707 & 0.719 & 0.979 & 0.975 & 0.990 \\
\hline France & 1.021 & 1.111 & 0.856 & 0.434 & 0.389 \\
\hline Ghana & 1.654 & 1.708 & 1.498 & 1.667 & 1 \\
\hline Hungary & 1.460 & 1.891 & 1.333 & 1.452 & 0.011 \\
\hline India & 0.999 & 0.333 & 0.275 & 0.389 & 1 \\
\hline Iraq & 0.457 & 0.481 & 0.513 & 0.889 & 1 \\
\hline Sweden & 1.289 & 1.667 & 1.334 & 1.567 & 1.654 \\
\hline Italy & 0.221 & 0.894 & 1.443 & 1.191 & 0.446 \\
\hline Bulgaria & 0.222 & 0.356 & 0.358 & 0.188 & 0.306 \\
\hline Croatia & 0.243 & 0.671 & 0.280 & 0.888 & 0.132 \\
\hline Jordan & 0.267 & 0.456 & 0.289 & 0.356 & 0.441 \\
\hline Malta & 1.434 & 1.896 & 0.456 & 0.444 & 1.498 \\
\hline Mongolia & 1.785 & 1.690 & 1.604 & 1.909 & 1.333 \\
\hline Vietnam & 0.708 & 2.753 & 0.527 & 0.234 & 0.275 \\
\hline Oman & 0.456 & 0.566 & 0.187 & 0.384 & 0.255 \\
\hline Pakistan & 0.129 & 0.316 & 0.271 & 0.255 & 0.006 \\
\hline Russia & 0.894 & 0.319 & 0.388 & 0.110 & 1.021 \\
\hline Poland & 0.121 & 0.477 & 0.498 & 0.489 & 0.671 \\
\hline Romania & 0.355 & 0.787 & 0.356 & 0.439 & 0.356 \\
\hline CommaHM/axjs & & & & 0.30 \\
\hline
\end{tabular}




\begin{tabular}{|llllll|}
\hline Countries & $\mathbf{2 0 1 6}$ & $\mathbf{2 0 1 7}$ & $\mathbf{2 0 1 8}$ & $\mathbf{2 0 1 9}$ & $\mathbf{2 0 2 0}$ \\
\hline Taiwan & 0.354 & 0.990 & 0.289 & 0.241 & 0.558 \\
\hline Qatar & 0.132 & 0.558 & 0.345 & 0.306 & 1.021 \\
\hline
\end{tabular}

In this region, economic development, attractiveness and technology are less than in the East, but greater than in the West. In the north-east there are also heavy industries. They are producing and exporting millions of tons of coal eastwards. Higher technology boosts the economy of the nation and confronts the $\mathrm{CO} 2$ emission countries with the finest power reforms. Based on the aforementioned findings, we concluded that technological development is one of the key reasons for energy efficiency and electricity reform. This development typically involves a decrease in the intensity of energy. Even while this decrease in energy intensity in some developing economies such as China has already been seen, it is still greater than many other nations in the globe, particularly highly developed ones. In this instance, it is an efficient method to increase energy efficiency using energy technology for emerging countries. Furthermore, it has been noted that most developing and rising countries still rely significantly on non-renewable energy sources such as fossil fuels and coal despite their active reform of their energy consumption structures as well as their strong efforts to create clean energy and renewables. Therefore, the basic structural adjustments in energy production, distribution and consumption seem to be required. Reforms on the markets presently play a significant influence in national advances in renewable energy. The fast economic developments in developing countries such as China have drawn lots of attention from the government, academics and the public. 
Table 2

Weighted data scores

\begin{tabular}{|c|c|c|c|c|}
\hline & \\
\hline DMU & Scores & VX 1 (GF) & UY 1 (REG) & UY 2 (EE) \\
\hline Austria & 0.311 & 0.64 & 0.33 & 0.70 \\
\hline Azerbaijani & 0.144 & 0.51 & 0.29 & 0.88 \\
\hline Belgium & 0.432 & 0.40 & 0.11 & 1.00 \\
\hline Chile & 0.744 & 0.36 & 0.01 & 0.33 \\
\hline Finland & 0.622 & 0.39 & 0.99 & 0.11 \\
\hline Germany & 0.216 & 0.27 & 0.00 & 0.40 \\
\hline Denmark & 0.507 & 0.24 & 0.13 & 0.84 \\
\hline Fiji & 0.767 & 0.17 & 0.19 & 0.27 \\
\hline France & 1.004 & 0.37 & 0.66 & 0.51 \\
\hline Ghana & 1.654 & 0.78 & 0.14 & 0.60 \\
\hline Hungary & 1.499 & 0.81 & 0.21 & 0.45 \\
\hline India & 0.960 & 0.33 & 0.34 & 0.83 \\
\hline Iraq & 0.490 & 0.41 & 0.20 & 1.00 \\
\hline Sweden & 1.221 & 0.67 & 0.18 & 0.44 \\
\hline Italy & 0.201 & 0.84 & 0.67 & 0.38 \\
\hline Bulgaria & 0.145 & 0.36 & 0.80 & 0.21 \\
\hline Croatia & 0.267 & 0.71 & 0.55 & 0.77 \\
\hline Jordan & 0.201 & 0.21 & 0.32 & 0.49 \\
\hline Malta & 1.484 & 0.16 & 0.11 & 0.11 \\
\hline Mongolia & 1.734 & 0.89 & 0.17 & 0.55 \\
\hline Vietnam & 0.756 & 0.19 & 0.18 & 0.00 \\
\hline Oman & 0.429 & 0.51 & 0.44 & 1.00 \\
\hline Pakistan & 0.194 & 0.32 & 0.80 & 1.00 \\
\hline Russia & 0.821 & 0.23 & 0.79 & 0.45 \\
\hline Poland & 0.190 & 0.70 & 0.00 & 0.99 \\
\hline Romania & 0.354 & 0.71 & 0.00 & 0.82 \\
\hline utput/Commonk & ML/jax.js & 0.10 & 0.00 & 0.46 \\
\hline
\end{tabular}




\begin{tabular}{|lllll|}
\hline DMU & Scores & VX 1 (GF) & UY 1 (REG) & UY 2 (EE) \\
\hline Qatar & 0.101 & 0.55 & 0.56 & 0.67 \\
\hline
\end{tabular}

Energy overconsumption to address this problem, a succession of energy conservation laws have been established after the 21st century. Officials, as policymakers and executors, are certainly one of the main factors in resolving this issue. According to BP World Energy Statistical Review, China's total energy consumption occupied 23.2 percent of the worldwide market in 2017, holding top place for several years. Thus, improving energy efficiency has become important tasks to accomplish for growing economies such as the Chinese government.

In recent years, a number of energy and electricity regulations were adopted in power sector in emerging countries and the energy efficiency of generation, consumption or distribution is anticipated to be increased efficiently. The electricity industry is regarded one of the leading drivers of economic development. The installed thermal power plants that account for more or less $75 \%$ of the total capacity generated in the emerging countries. Coal is the major electrical fossil fuel, representing $90 \%$ of the thermal capacity built. Emerging countries such as Turkey are continually increasing its energy demand fast and this increasing requirement continues to be fulfilled via fossil fuel use, especially through coal burning for electricity. In 2018, electricity consumption was recorded up to 303.2 billion kilowatts an hour in a single developing country like Turquie, therefore indicating projected rise to 357.4 terawatts an hour (approximately $5.5 \%$ increase) by 2023. Furthermore, Turkey's energy consumption indices showed that coal was generated by $37.3 \%$ of power production in 2018 , while gas, hydropower, wind, solar, geothermal and other sources jointly produced by $29.8 \%, 19.8 \%, 6.6 \%, 2.6 \%$ and $2.5 \%$ in the same year. This explains the electricity percentage quantification.

As heavy industries in certain areas of this sector are very densely involved, energy consumption and associated pollutant emissions are considerable. The West spans more than half of the area of these nations and covers one municipality This region also has a low population density and a large stock of resources such as coal, oil, natural gas and other minerals in the other two places. The western region of these nations is also the least developed territory. However, it is well protected in certain parts of this area owing to the low density of industry and people. A comparison of three economic regions Tables show growth, energy usage and emission of pollutants. 
Table 3

Role of green financing before and during COVID-19 wave

\begin{tabular}{|c|c|c|c|c|}
\hline DMU & $\begin{array}{l}\text { Before COVID-19 } \\
\text { score }\end{array}$ & $\begin{array}{l}\text { Energy } \\
\text { efficiency }\end{array}$ & $\begin{array}{l}\text { After COVID-19 } \\
\text { score }\end{array}$ & Energy efficiency \\
\hline Austria & 0.00 & 0.70 & 0.91 & 0.56 \\
\hline Azerbaijani & 0.1 & 0.88 & 0.35 & 0.71 \\
\hline Belgium & 0.00 & 1.00 & 0.18 & 0.17 \\
\hline Chile & 0.04 & 0.33 & 0.90 & 0.21 \\
\hline Finland & 0.02 & 0.11 & 0.67 & 0.07 \\
\hline Germany & 0.06 & 0.40 & 0.80 & 0.07 \\
\hline Denmark & 0.05 & 0.84 & 0.45 & 0.33 \\
\hline Fiji & 0.00 & 0.27 & 0.66 & 0.11 \\
\hline France & 0.00 & 0.51 & 0.78 & 0.13 \\
\hline Ghana & 0.01 & 0.60 & 0.91 & 0.44 \\
\hline Hungary & 0.09 & 0.45 & 0.17 & 0.20 \\
\hline India & 0.56 & 0.83 & 0.88 & 0.17 \\
\hline Iraq & 0.03 & 1.00 & 0.44 & 0.67 \\
\hline Sweden & 0.02 & 0.44 & 0.21 & 0.23 \\
\hline Italy & 0.06 & 0.38 & 0.70 & 0.14 \\
\hline Bulgaria & 0.135 & 0.21 & 0.67 & 0.01 \\
\hline Croatia & 0.07 & 0.77 & 0.99 & 0.30 \\
\hline Jordan & 0.21 & 0.49 & 0.89 & 0.21 \\
\hline Malta & 0.44 & 0.11 & 0.91 & 0.08 \\
\hline Mongolia & 0.34 & 0.55 & 0.77 & 0.05 \\
\hline Vietnam & 0.74 & 0.00 & 0.72 & 0.67 \\
\hline Oman & 0.21 & 1.00 & 0.33 & 0.34 \\
\hline Pakistan & 0.00 & 1.00 & 0.29 & 0.15 \\
\hline Russia & 0.00 & 0.45 & 0.89 & 0.34 \\
\hline Poland & 0.00 & 0.99 & 0.44 & 0.21 \\
\hline Romania & 0.00 & 0.82 & 0.55 & 0.05 \\
\hline
\end{tabular}




\begin{tabular}{|lllll|}
\hline DMU & $\begin{array}{l}\text { Before COVID-19 } \\
\text { score }\end{array}$ & $\begin{array}{l}\text { Energy } \\
\text { efficiency }\end{array}$ & $\begin{array}{l}\text { After COVID-19 } \\
\text { score }\end{array}$ & Energy efficiency \\
\hline Taiwan & 0.00 & 0.46 & 0.61 & 0.18 \\
\hline Qatar & 0.00 & 0.67 & 0.80 & 0.22 \\
\hline
\end{tabular}

Figure 2 shows that Luxembourg as Asia Pacific's fastest growing economy has the greatest energy efficiency score of 1,596 and rank 1 in the area. Although Luxembourg's energy efficiency varied between 2010 and 2014, it tended to decline at an annual rate of $1.23 \%$. Increasing energy efficiency effects of energy market reform. The Netherlands and Germany rank second and third with respective energy efficiencies of 1,527 and 1,157 , which continue to rise at an average yearly pace of $1,93 \%$ and $0,73 \%$. Sweden and Ireland rank fourth and fifth with energy efficiency of 1,056 and 0,818 respectively.

However, Sweden's energy efficiency continues to decline at an annual average rate of 1.89 percent, unlike Ireland, where energy efficiency continues to improve. Italy and Spain rank sixth and seventh with energy efficiency score of 0.659 and 0.492 , respectively. UK and Portugal rank eighth and ninth with energy efficiency score of 0,398 and 0,261 respectively. Belgium and Finland rank 10th and 11th, with energy efficiency of 0.246 and 0.233 respectively. Poland and Denmark rank two and thirteenth with energy efficiency score of 0.221 and 0.204 , respectively.

Croatia and Austria rank fourteenth and fifteenth with 0.203 and 0.202 energy efficiency score respectively. Greece and France rank seventeenth and seventeenth with energy efficiency score 0.176 and 0.170 respectively. Bulgaria and Czech Republic are eighteenth and nineteenth with energy efficiency score of 0.163 and 0.159 respectively. Romania and Estonia rank twenty-first and twenty-first, with energy efficiency of 0.142 and 0.141 respectively. Malta and Slovenia rank twenty-second and twenty-third, with energy efficiency of 0.139 and 0.136 respectively. Slovakia and hungry ranked twenty-fourth and twentyfifth with energy efficiency of 0.123 and 0.121 , respectively. Cyprus, Lithuania and the latter are ranked twenty-sixth, seventh and eighth with an energy efficiency score of 0.1070 .099 and 8.56 respectively.

Table 4

Findings of sensitivity analysis

\begin{tabular}{|c|c|c|c|c|c|}
\hline & Case Rank & Case-1 & Case-2 & Case-3 & Case-4 \\
\hline PS1 & 1 & 1 & 1 & 1 & 1 \\
\hline PS2 & 4 & 4 & 4 & 4 & 4 \\
\hline PS3 & 7 & 7 & 7 & 7 & 7 \\
\hline PS4 & 3 & 3 & 3 & 3 & 3 \\
\hline
\end{tabular}

In this study, we use annual capital and labour data as two non-energy inputs and energy consumption as we use gross domestic product (GDP) as the desired product and renewable energy generation as 


\section{Discussion}

Under this scenario, most people in nations saw extremely high environmental efficiency. Meanwhile, we must understand that the non-parameter boundary approach is a technique to measure the relative effectiveness of decision-making units. At this time, however, the average environmental value for energy efficiency throughout the country was much lower than $96.02 \%$ (with "environmental regulation in the eyes of individual provinces, there is a significant difference in the environmental efficiency of two types of situations.

A composite indicator combines multiple indicators into one index. The index is used to assess complicated ideas not captured by a single indicator. To create a meaningful composite indicator that may offer important decision-making information at national or worldwide level, the composite indexing process must be transparent to guarantee the future (Iqbal et al, 2021). Lower Renewable electricity generation increase energy efficiency with improved policy making in all research countries for future energy market. Renewable electricity generation his study focuses on market reforms and decrees greenhouse gases save environmental impacts (lqbal et al, 2021). Energy efficiency drew significant attention from both academics and practitioners ( $\mathrm{Li}$ et al, 2021). This increasing emphasis on energy efficiency relates to the significance of energy consumption in today's society. Energy, obviously, is the lifeblood of economic growth and an essential factor in a country's socio-economic development and power markets. No country can achieve economic development without huge energy. Countries must provide adequate and affordable energy supply.

Based on the aforementioned findings, ensuring adequate energy is not enough for Asia-Pacific nations (Sovacool, 2011). The aim stresses ecologically friendly energy production method and sources. In other words, energy sources are clean, not harming the environment (Yang and Hanson, 2009). Most energy now originates from fossil fuel burning. Fossil fuel burning process produces carbon emissions and other greenhouse gases, which are environmentally harmful and contribute to climate change (Vivoda, 2010). Therefore, ensuring energy security while also preserving the environment is essential. Accordingly, this thesis' goals are: assessing energy efficiency and sustainability at regional and national level, evaluate and propose green and sustainable energy routes for energy security and climate change mitigation, energy reforms for Asia-Pacific are linked to energy efficiency.

\section{Conclusion And Policy Implication}

This research was performed to identify Asia-Pacific nations' energy efficiency as a crucial element in reforming energy markets and maintaining economic development as the basis of the national economy. In recent years, with the increasing modernization of the economy of these nations and expanding urbanization, energy consumption has risen significantly; generating environmental issues caused by energy usage would raise broad concern worldwide. Society. Research on the environmental efficiency of energy consumption in the provinces of these nations may offer a foundation for decision-making in the formulatinn of onorav and onvirnnmontal nalicies and policy reforms. Renewable energy development Loading [MathJax]/jax/output/CommonHTML/jax.js 
and policy implications presented in this research may assist the government overcome these obstacles to a seamless transition to renewable power.

The outcomes are many points. (1) Environmental energy efficiency in study 28 nations and their provinces still has lots of space to enhance energy efficiency, and production growth and $\mathrm{CO} 2$ emission reduction still have promise. (2) As demonstrated in the non-parameter test findings, energy efficiency in three main areas These nations have substantial geographical variations, exhibiting a development pattern The East-Middle-West and Eastern region efficiency are greater than the Central and Western, moreover, the difference between them continues to grow. Combining energy efficiency with environmental energy in three areas is helpful in study. (3) After reviewing the loss of efficiency caused by regulatory and environmental regulatory costs in 2014 for each province, showing that most provinces have environmental regulatory costs and that their economic development depends primarily on environmental capacity with significant environmental costs for economic growth. Therefore, altering economic development mode and enhancing environmental quality is an essential need.

Within a joint production framework of both favorable output (GDP) and unfavorable output (CO2 and SO2), as well as energy input (total energy consumption) and non-energy input (labor and capital stock), this study uses an envelope-based data-set model to evaluate the total energy and environmental efficiency factor of 25 administrative regions and three of these countries. This research also uses DEA window analysis methods to evaluate efficiency on cross-sectional and data-varying data to compute efficiency score throughout the periods of study 2010-2014. And empirical findings indicate that these nations' eastern region has better energy and environmental efficiency than the center area, and the westward area's efficiency is lowest. The efficiency of all three sectors varies similarly, and typically, the energy and environmental efficiency of these nations improved somewhat from 2016 to 2020. The Eastern region's energy and energy efficiency and environment do better than the middle and western regions. These nations enhance market reforms with lower-price future energy markets.

Differences in the three regions' efficiency may come from the economic development imbalance, not too much. High energy and country-wide environmental efficiency may be induced by the economic growth style of these nations. Effective energy and environmental protection regulations established and implemented by government during the last decade, however, may have helped to improving energy and environmental efficiency. Electricity market reforms in Asia-Pacific nations offer more precise data availability in various policy making periods, and greater energy efficiency provides stronger market changes. Indeed, a series of significant policy changes in these areas are currently underway and have produced tangible benefits. Energy prices have been modified since2010, high-tech, less energy-intensive smartphone and mobile device manufacturing has increased export shares, and the importance of the economy's state sector has progressively decreased with private sector growth. In addition to this positive phenomenon, there is the current trend globally towards green and sustainable energy usage, which has a direct impact on APE's energy production agenda. 
Ethics approval and consent to participate: Not applicable.

Consent for publication: Not applicable.

Availability of data and materials: Not applicable.

Competing interests: The authors declare that they have no competing interests.

Funding: National Natural Science Foundation of China: International Cooperation (NSFC: 71911530164); National Natural Science Foundation of China『NSFC $₫ 72074114 \rrbracket$

Authors' contributions: All authors contributed to the study conception and design. Material preparation and data collection were performed by Jinhang Xu and Yiming Wei, data analysis were performed by Zhen Liu and Assem Abu Hatab. The first draft of the manuscript was written by Yiming Wei, the final manuscript edited by Jinhang Xu and all authors commented on previous versions of the manuscript. All authors read and approved the final manuscript. The whole work supervised by Jing Lan.

\section{References}

1. Adland, R., Jia, H., and Strandenes, S. P., 2017. Are AIS-based trade volume estimates reliable? The case of crude oil exports. Maritime Policy \& Management 44(5), 657-665. https://doi.org/10.1080/03088839.2017.1309470.

2. Agnolucci, P., Smith, T., and Rehmatulla, N., 2014. Energy efficiency and time charter rates: Energy efficiency savings recovered by ship owners in the Panamax market. Transportation Research Part A: Policy and Practice 66, 173-184. https://doi.org/10.1016/j.tra.2014.05.004.

3. Alemzero, D. A., Iqbal, N., lqbal, S., Mohsin, M., Chukwuma, N. J., and Shah, B. A., 2021. Assessing the perceived impact of exploration and production of hydrocarbons on households perspective of environmental regulation in Ghana. Environmental Science and Pollution Research 28(5), 5359-5371. https://doi.org /10.1007/s11356-020-10880-3.

4. Anh Tu, C., Chien, F., Hussein, M. A., Ramli MM, Y., Psi MM, M. S. S., lqbal, S., and Bilal, A. R., 2021. Estimating role of Green Financing on Energy Security, Economic and Environmental Integration of BRI member countries. The Singapore Economic Review. https://doi.org/10.1142/S0217590821500193.

5. Bal, Y., Faure, M., and Liu, J., 2014. The role of China's banking sector in providing green finance. Duke Envtl. L. \& Pol'y F. 24, 89.

6. Barbier, E. B., 2020. Greening the post-pandemic recovery in the G20. Environmental and Resource Economics 76(4), 685-703. https:// doi.org /10.1007/s10640-020-00437-w.

7. Bersalli, G., Menanteau, P., and El-Methni, J., 2020. Renewable energy policy effectiveness: A panel data analysis across Europe and Latin America. Renewable and Sustainable Energy Reviews 133, 110351. https://doi.org/10.1016/j.rser.2020.110351. 
8. Campisi, D., Gitto, S., and Morea, D., 2018. Economic feasibility of energy efficiency improvements in street lighting systems in Rome. Journal of Cleaner Production 175, 190-198. https://doi.org/10.1016/j.jclepro.2017.12.063.

9. Carrasco, J. M., Franquelo, L. G., Bialasiewicz, J. T., Galván, E., PortilloGuisado, R. C., Prats, M. M., Leon, J. I., and Moreno-Alfonso, N., 2006. Power-electronic systems for the grid integration of renewable energy sources: A survey. IEEE Transactions on industrial electronics 53(4), 1002-1016. https://doi.org/ 10.1109/TIE.2006.878356.

10. Caruso, G., Colantonio, E., and Gattone, S. A., 2020. Relationships between renewable energy consumption, social factors, and health: a panel vector auto regression analysis of a cluster of $12 \mathrm{EU}$ countries. Sustainability 12(7), 2915. https://doi.org/10.3390/su12072915.

11. Cheng, Y., and Yao, X., 2021. Carbon intensity reduction assessment of renewable energy technology innovation in China: A panel data model with cross-section dependence and slope heterogeneity. Renewable and Sustainable Energy Reviews 135, 110157. https://doi.org/10.1016/j.rser.2020.110157.

12. Child, M., Koskinen, O., Linnanen, L., and Breyer, C., 2018. Sustainability guardrails for energy scenarios of the global energy transition. Renewable and Sustainable Energy Reviews 91, 321-334. https://doi.org/10.1016/j.rser.2018.03.079.

13. Corrocher, N., and Cappa, E., 2020. The Role of public interventions in inducing private climate finance: An empirical analysis of the solar energy sector. Energy Policy 147, 111787. https://doi.org/10.1016/j.enpol.2020.111787.

14. Erdogan, S., Okumus, I., and Guzel, A. E., 2020. Revisiting the Environmental Kuznets Curve hypothesis in OECD countries: the role of renewable, non-renewable energy, and oil prices. Environmental Science and Pollution Research 27(19), 23655-23663. https://doi.org /10.1007/s11356-020-08520-x.

15. Eto, H., Kato, H., Suga, H., Aoi, N., Doi, K., Kuno, S., and Yoshimura, K., 2012. The fate of adipocytes after nonvascularized fat grafting: evidence of early death and replacement of adipocytes. Plastic and reconstructive surgery 129(5), 1081-1092. https://doi.org /10.1097/PRS.0b013e31824a2b19.

16. Falcone, P. M., and Sica, E., 2019. Assessing the opportunities and challenges of green finance in Italy: An analysis of the biomass production sector. Sustainability 11(2), 517. https://doi.org/10.3390/su11020517.

17. Gielen, D., Boshell, F., Saygin, D., Bazilian, M. D., Wagner, N., and Gorini, R., 2019. The role of renewable energy in the global energy transformation. Energy Strategy Reviews 24, 38-50. https://doi.org/10.1016/j.esr.2019.01.006.

18. Göhlich, D., Nagel, K., Syré, A. M., Grahle, A., Martins-Turner, K., Ewert, R., Jahn, R. M., and Jefferies, D., 2021. Integrated approach for the assessment of strategies for the decarbonization of urban traffic. Sustainability 13(2), 839. https://doi.org/10.3390/su13020839.

19. Iqbal, S., Bilal, A. R., Nurunnabi, M., Iqbal, W., Alfakhri, Y., and Iqbal, N., 2021. It is time to control the 
and Pollution Research 28(15), 19008-19020. https://doi.org/10.1007/s11356-020-11462-z.

20. Iqbal, S., Taghizadeh-Hesary, F., Mohsin, M., and Iqbal, W., 2021. Assessing the Role of the Green Finance Index in Environmental Pollution Reduction. Studies of Applied Economics 39(3).

21. Kabir, E., Kumar, P., Kumar, S., Adelodun, A. A., and Kim, K. H., 2018. Solar energy: Potential and future prospects. Renewable and Sustainable Energy Reviews 82, 894-900.

https://doi.org/10.1016/j.rser.2017.09.094.

22. Kılkış, Ş., 2019. Benchmarking the sustainability of urban energy, water and environment systems and envisioning a cross-sectoral scenario for the future. Renewable and Sustainable Energy Reviews 103, 529-545. https://doi.org/10.1016/j.rser.2018.11.006.

23. Koroneos, C., Spachos, T., and Moussiopoulos, N., 2003. Exergy analysis of renewable energy sources. Renewable energy 28(2), 295-310. https://doi.org/10.1016/S0960-1481(01)00125-2.

24. Kreps, B. H., 2020. Energy Sprawl in the Renewable-Energy Sector: Moving to Sufficiency in a PostGrowth Era. American Journal of Economics and Sociology 79(3), 719-749. https://doi.org/10.1111/ajes.12346.

25. Li, W., Chien, F., Hsu, C. C., Zhang, Y., Nawaz, M. A., Iqbal, S., and Mohsin, M., 2021. Nexus between energy poverty and energy efficiency: Estimating the long-run dynamics. Resources Policy 72, 102063. https://doi.org/10.1016/j.resourpol.2021.102063.

26. Maczulak, A. E., 2010. Renewable energy: sources and methods. Infobase Publishing.

27. Mihelcic, J. R., and Zimmerman, J. B., 2021. Environmental engineering: Fundamentals, sustainability, design. John wiley \& sons.

28. Mohsin, M., Kamran, H. W., Nawaz, M. A., Hussain, M. S., and Dahri, A. S., 2021. Assessing the impact of transition from nonrenewable to renewable energy consumption on economic growthenvironmental nexus from developing Asian economies. Journal of environmental management 284, 111999. https://doi.org/10.1016/j.jenvman.2021.111999.

29. Panwar, N. L., Kaushik, S. C., and Kothari, S., 2011. Role of renewable energy sources in environmental protection: A review. Renewable and sustainable energy reviews 15(3), 1513-1524. https://doi.org/10.1016/j.rser.2010.11.037.

30. Rasoulinezhad, E., Taghizadeh-Hesary, F., Sung, J., and Panthamit, N., 2020. Geopolitical risk and energy transition in russia: Evidence from ARDL bounds testing method. Sustainability 12(7), 2689. https://doi.org/10.3390/su12072689.

31. Shahbaz, M., Raghutla, C., Chittedi, K. R., Jiao, Z., and Vo, X. V., 2020. The effect of renewable energy consumption on economic growth: Evidence from the renewable energy country attractive index. Energy 207, 118162. https://doi.org/10.1016/j.energy.2020.118162.

32. Sovacool, B. K., 2011. Evaluating energy security in the Asia pacific: Towards a more comprehensive approach. Energy policy 39(11), 7472-7479. https://doi.org/10.1016/j.enpol.2010.10.008.

33. Taghizadeh-Hesary, F., and Yoshino, N., 2020. Sustainable solutions for green financing and investment in renewable energy projects. Energies 13(4), 788. https://doi.org/10.3390/en13040788. 
34. Tiwari, G. N., and Mishra, R. K., 2012. Advanced renewable energy sources. Royal Society of Chemistry.

35. Vivoda, V., 2010. Evaluating energy security in the Asia-Pacific region: A novel methodological approach. Energy policy 38(9), 5258-5263. https://doi.org/10.1016/j.enpol.2010.05.028.

36. Wang, Y., and Zhi, Q., 2016. The role of green finance in environmental protection: Two aspects of market mechanism and policies. Energy Procedia 104, 311-316.

https://doi.org/10.1016/j.egypro.2016.12.053.

37. Winkel, L. H., Vriens, B., Jones, G. D., Schneider, L. S., Pilon-Smits, E., and Bañuelos, G. S., 2015.

Selenium cycling across soil-plant-atmosphere interfaces: a critical review. Nutrients 7(6), 4199-4239. https://doi.org/10.3390/nu7064199.

38. Yang, R. Y., and Hanson, P. M., 2009. Improved food availability for food security in Asia-Pacific region. Asia Pacific journal of clinical nutrition 18(4), 633.

39. Zhou, X., Tang, X., and Zhang, R., 2020. Impact of green finance on economic development and environmental quality: a study based on provincial panel data from China. Environmental Science and Pollution Research 27(16), 19915-19932. https://doi.org /10.1007/s11356-020-08383-2.

\section{Figures}

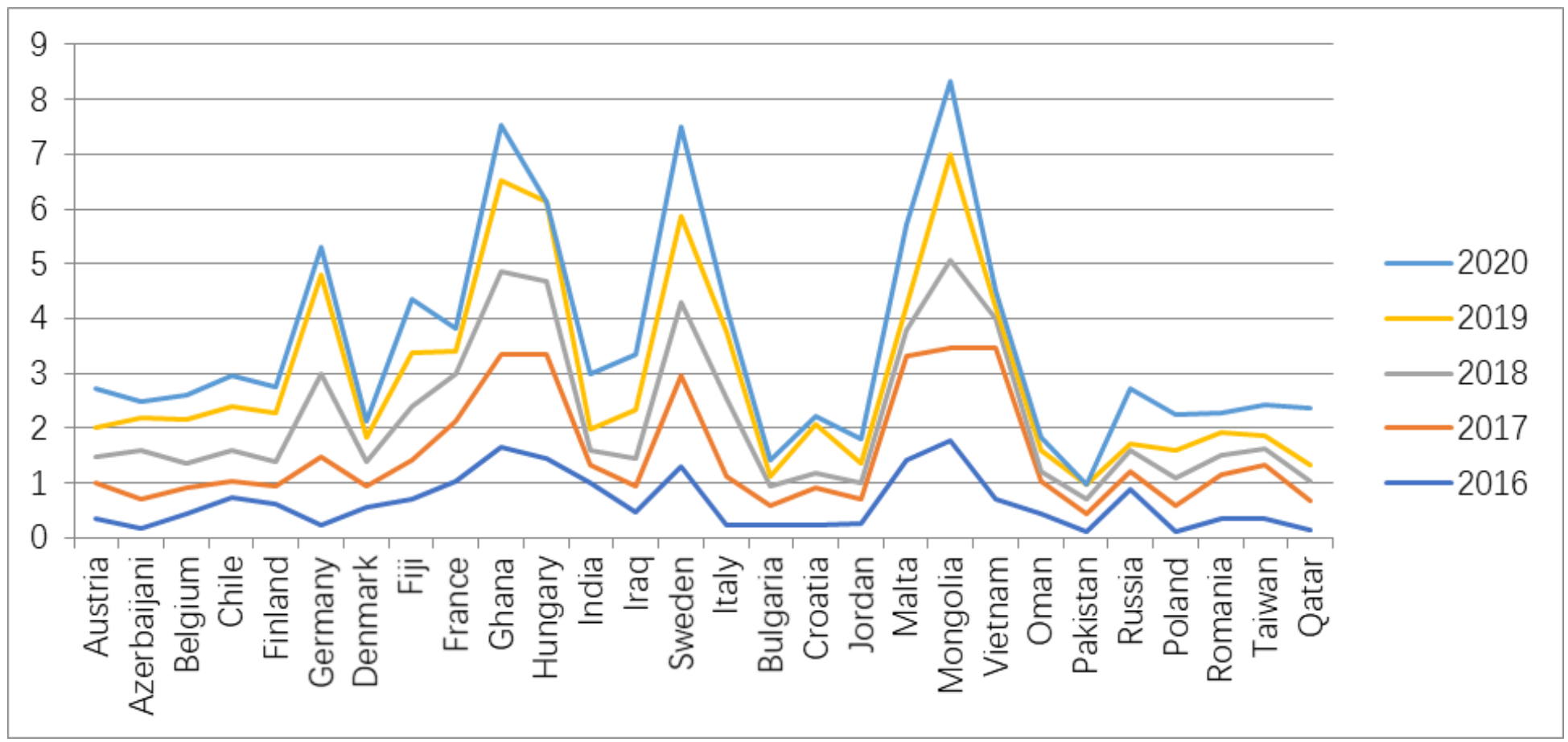

\section{Figure 1}

Renewable energy efficiency through electricity generation 


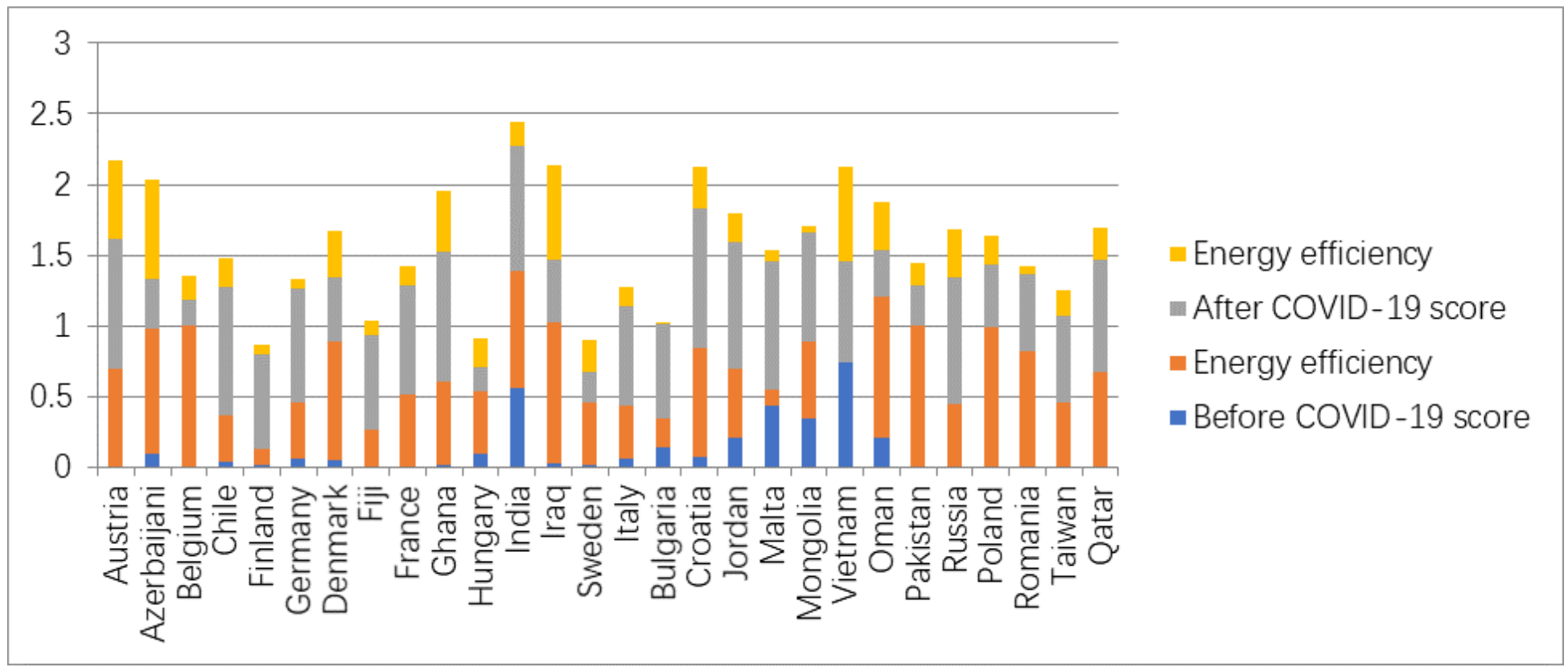

Figure 2

Green financing influences on study constructs

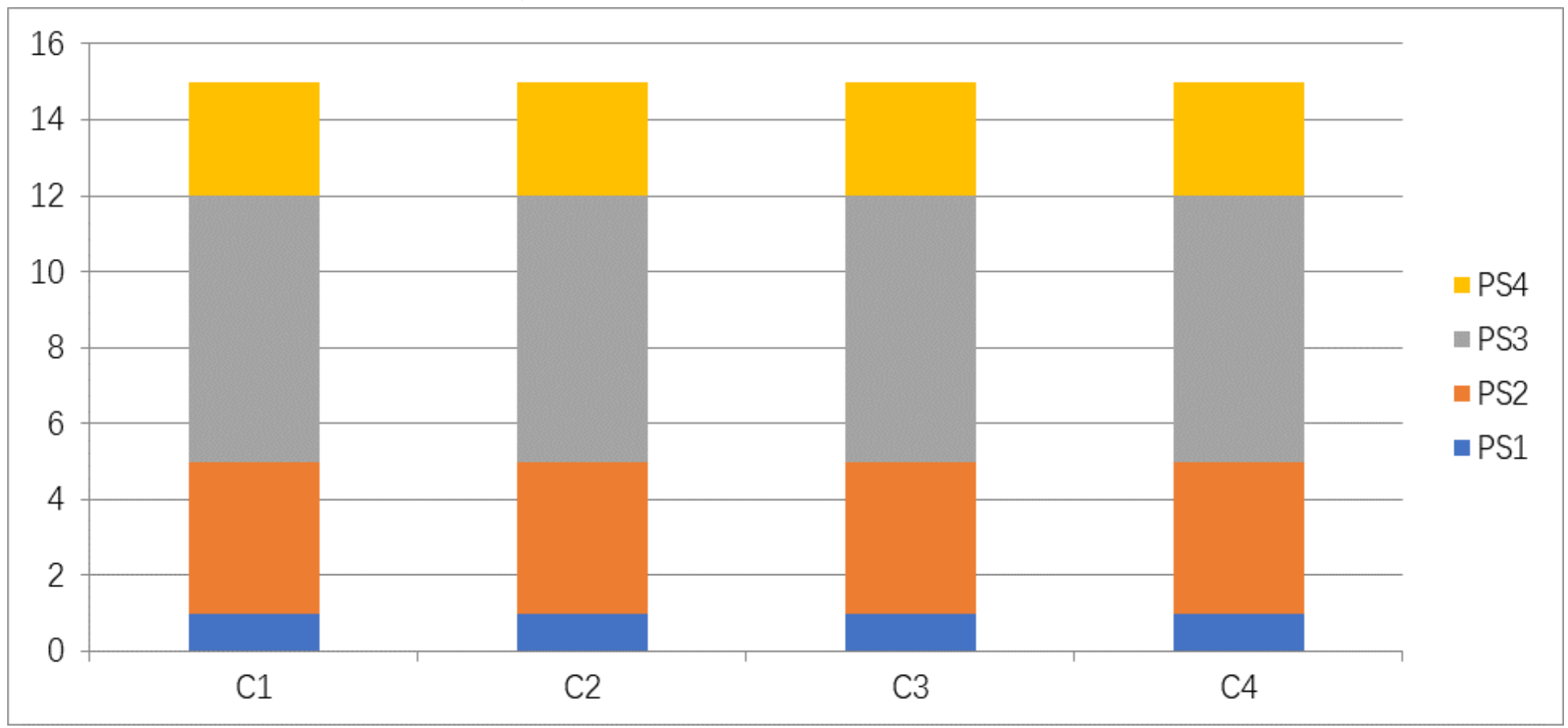

Figure 3

Case-wise role of indicators and their sensitivity responses 